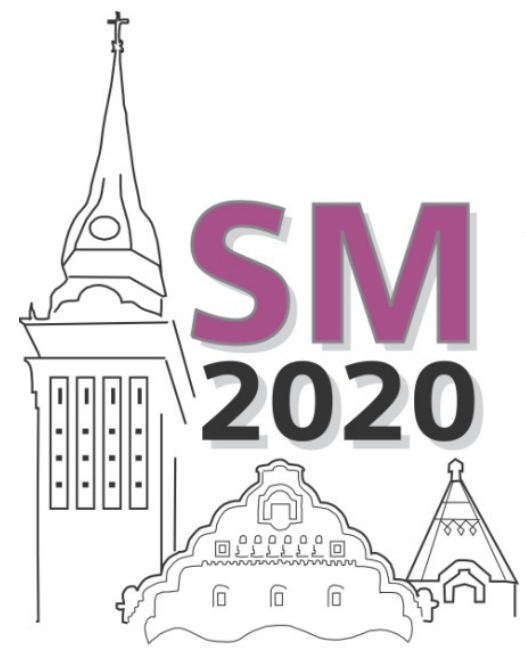

Predrag Mali

University of Novi Sad, Faculty of Tehnical Science

Novi Sad, Serbia

predragmali@yahoo.com

\section{Milan Nikolić}

University of Novi Sad, Technical Faculty

"Mihajlo Pupin"

Zrenjanin, Serbia

mikaczr@sbb.rs 25th International Scientific Conference

Strategic Management and Decision Support Systems

in Strategic Management

$19^{\text {th }}$ May, 2020, Subotica, Republic of Serbia

\title{
ORGANIZATIONAL FINANCIAL PERFORMANCE AND ENTREPRENEURIAL INTENTIONS AMONG EMPLOYED PERSONS
}

\begin{abstract}
The paper presents the results of the study of the influence of the organizational financial performance on individual entrepreneurial orientation dimensions, achievement dimension and the theory of planned behaviour dimensions, among employed persons. Respondents were employed persons in organizations in Serbia. The final sample consists of 540 respondents from 72 companies. Of the financial performance items, Market share, then Sales growth and Asset growth have the strongest impact on the individual entrepreneurial orientation dimensions, achievement dimension and the theory of planned behavior dimensions. The weakest influence has the Salaries item: the perceived salary level has no significant effect on the observed dimensions. However, regression analysis showed that the Salaries item has a statistically significant and negative predictive effect on the dimension Subjective norm. The theoretical significance of this research is that very few papers address entrepreneurial intentions among employed persons. The practical significance of the paper is that it shows that employed persons should definitely be counted as potential entrepreneurs.
\end{abstract}

Keywords: Financial Performance, Entrepreneurial Intentions, Employed Persons.

\section{INTRODUCTION}

Numerous researchers have emphasized the role of entrepreneurship in economic as well as social development, for example (Brandstätter, 2011; Muzychenko, 2008). More specifically, the importance of entrepreneurship is reflected in the fact that it is the main source of employment, economic growth, technological progress, innovation, competition and economic flexibility (Obschonka \& Stuetzer, 2017; Hisrich, Langan-Fox, \& Grant, 2007; Mortan, Ripoll, Carvalho, \& Bernal, 2014). Paul and Shrivatava (2016), point out that entrepreneurship creates wealth and reduced unemployment at 
the level of society as a whole. As a result, the concepts and philosophy of entrepreneurship are becoming widely accepted by state institutions, relevant ministries, and organizations (Hisrich, Peters, \& Shepherd, 2008).

Entrepreneurship, therefore, is becoming an extremely important area for scientific research globally. A significant amount of this research focuses on identifying the causes, drivers and ways in which entrepreneurial intentions emerge in individuals. According to The Theory of Planned Behavior (Ajzen, 1991), intentions are a major indicator of later behavior. This theory maps perfectly to entrepreneurship, so the entrepreneurial intentions of an individual, with a high degree of probability, indicate his or her future entrepreneurial behavior and start-up business.

Employees are often neglected as respondents in entrepreneurial intent surveys. This seems logical at first glance. However, employees actually have more experience and knowledge than unemployed persons, better know the economic conditions and needs, and thus have a greater chance of coming up with a quality idea for an entrepreneurial venture, and also have more knowledge and financial ability to realize those ideas (Khotin, 2016; Hormiga, Hancock, \& Valls-Pasola, 2013). For this reason, some authors, for example (Hormiga, Hancock, \& Valls-Pasola, 2013; Marshall \& Gigliotti, 2018), consider that more attention needs to be paid to the entrepreneurial intentions of employees. Examples of such research are not numerous, but they do exist (Kautonen, Luoto, \& Tornikoski, 2010; Hatak, Harms, \& Fink, 2015; Virick, Basu, \& Rogers, 2015; Feola, Vesci, Botti, \& Parente, 2019).

The question may be raised here: why would an employee think about starting their own business? The answer to this question is, in fact, simple: for the same reasons as an unemployed person. These reasons are related to the realization of their own ideas, gaining freedom and independence, the possibility of high financial earnings, the affirmation of personal creativity and ability, the need for achievement and self-affirmation, etc. In addition, unlike the unemployed, employees may find motivation for taking entrepreneurial action in some aspects of life and work in the organization where they are currently employed. For example, the emergence of entrepreneurial intentions in employees may be influenced by the perception of low pay (Werner, Gast, \& Kraus, 2014; Sorgner \& Fritsch, 2018), disagreement with corporate policy, low job satisfaction, inability to move forward (Minarcine \& Shaw, 2016 ), low job satisfaction, caused by low earnings and poor opportunities for promotion (Shinnar \& Young, 2008), limited job opportunities (Mallon \& Cohen, 2001; Hughes, 2003), low job satisfaction and dissatisfaction with superiors (Hyytinen \& Ilmakunnas, 2007), transactional leadership (the punishment part) and leader's unethical behavior (Mali, Kuzmanovic, Nikolic, Mitic, \& Terek, 2019), adverse organizational climate (Hsu, Shinnar, Powell, \& Coffey, 2017).

In this paper, entrepreneurial intentions of employed persons are examined, depending on organizational financial performance. More specifically, the research problem in this paper is the influence of organizational financial performance on individual entrepreneurial orientation dimensions, achievement dimension and theory of planned behavior dimensions, among employed persons. The aim of the research is to determine whether there are observed impacts and their direction, ie, whether entrepreneurial intentions of employees can be strengthened or weakened depending on the current financial performance of the organization in which they are employed? It is possible that an adverse financial situation of an organization enhances entrepreneurial attitudes and intentions of employees, and the opposite may occur: a favorable financial situation enhances the safety of employees, who then develop stronger entrepreneurial intentions. The research was conducted in organizations in Serbia. The theoretical significance of the paper is that it addresses a topic that has hitherto been largely unjustifiably neglected in the literature. The practical importance of the work is that it indicates the possibility of action of state institutions in the direction of promoting entrepreneurial intentions and behavior of employed persons.

\section{THEORY AND HYPOTHESIS}

As noted above, there are few references to examining entrepreneurial intentions with people who are employed in an existing business. The results of some of these studies are summarized below. The influence of age of employed persons on entrepreneurial intentions has been the subject of some research. For example, Hatak, Harms and Fink (2015) found that entrepreneurial intentions decreased with increasing age of employees. According to (Kautonen, Luoto, \& Tornikoski, 2010), older employees (50-64) who have spent most of their careers as blue collar workers in the industry are less prone to entrepreneurship than the general population in Finland. However, when it comes to employees in the public sector or small business, work history (practically, those are years of age) has no effect on entrepreneurial intentions, that is, older employees in these sectors have similar EIs relative to the general population.

The research conducted in reference (Virick, Basu, \& Rogers, 2015) refers to the study of entrepreneurial intentions in employees who are relaxed in their behavior. In doing so, the attention of researchers has focused on the attitude towards dismissal in order to start an entrepreneurial venture. Relaxed individuals have been shown to have a negative attitude towards dismissal if they have financial difficulties. On the other hand, the attitude towards dismissal becomes positive if the relaxed person is at the same time open to change. Although this research has a somewhat specific sample, it is significant because it studies the willingness to quit a current job due to aspirations to start one's own business.

One research group looks at entrepreneurial intentions in academic settings. For example, research (Huyghe \& Knockaert, 2015), in which the respondents were research scientists from Swedish and German universities, was conducted to examine the impact of organizational (university) culture and climate on entrepreneurial intention of the researchers. The presence of university role models and climate that fosters entrepreneurship has certainly been shown to have a positive impact on research scientists' propensity to engage in entrepreneurial activities, in spin-off creation and intellectual 
propensity rights, patenting or licensing intentions, but not in industry-science interaction. It should be borne in mind that the research conditions are specific because they are university researchers: they do not have to abandon their academic careers (current jobs) for these activities, so the risks are also much smaller. Furthermore, research into the impact on academic entrepreneurial intentions, conducted among scientists in South Africa (Urban \& Chantson, 2019) showed that attitude toward behavior has the strongest influence. Practically, awareness of, and exposure to, different entrepreneurial elements, significantly shapes the beliefs and attitudes of scholars toward academic entrepreneurship. According to (Feola, Vesci, Botti, \& Parente, 2019), entrepreneurial intentions in young researchers (academic EI) are influenced by all dimensions of the theory of planed behavior (TPB), but also by variables such as government and industrial / financial support.

References exploring employees' intentions to leave work, which they currently do, but without considering their entrepreneurial intentions, are much more numerous. For example, research (Kickul, 2001) found that, in small businesses, perceived unfulfilled promises have a significant impact on employee attitudes and commitments, as well as their intentions to leave the organization. According to (Monsen \& Boss, 2009), by increasing the ambiguity role, the intention to quit increases. Some other studies confirm that ambiguity role (Ashforth \& Saks, 1996) and uncertainty associated with organizational change (Rafferty \& Griffin, 2006) have a positive effect on the intention to quit. A study among Thai hotel employees (Ariyabuddhiphongs \& Marican, 2015) found that the Big Five personality traits negatively predicted turnover intention. Also, job satisfaction is a mediator of this relationship.

Two hypotheses were set up:

H1: There is a statistically significant influence of some organizational financial performance items and the financial performance dimension on individual entrepreneurial orientation dimensions, achievement dimension and the theory of planned behavior dimensions, among employed persons.

$\mathrm{H} 2$ : There is a statistically significant predictive effect of some organizational financial performance items on individual entrepreneurial orientation dimensions, achievement dimension and theory of planned behavior dimensions, among employed persons.

\section{METHOD}

\subsection{Survey instruments (measures)}

For measuring individual entrepreneurial orientation, the Individual Entrepreneurial Orientation (IEO) instrument was used (Bolton \& Lane, 2012). The questionnaire consists of 10 items and 3 dimensions: 1. Risk-taking, 2. Innovativeness and 3. Proactiveness. The items are valued through seven-point Likert scale.

The need for achievement was measured through the Achievement dimension from the Attitude Toward Enterprise (ATE) Test (Athayde, 2009). The dimension consists of 4 items. The items are valued through seven-point Likert scale.

The Entrepreneurial Intention Questionnaire (EIQ) (Liñán \& Chen, 2009) was used to measure the dimensions of The theory of planned behaviour. The questionnaire consists of 20 items and 4 dimensions: 1 . Personal attitude, 2. Subjective norm, 3. Perceived behavioural control and 4. Entrepreneurial intention. The items are valued through seven-point Likert scale.

Financial performance, as measured in this paper, is selected based on performance that has often been measured in the literature, for example (Tan \& Litschert, 1994; Wang, Tsui, Zhang, \& Ma, 2003; Wang, Tsui, \& Xin, 2011). In these references, the following financial performance is examined: profitability, sales growth, asset growth, market share, and competitive status in the firm's industry. In addition to these performances, two more are observed: productivity and salaries. Thus, a set of 7 financial performance (items), as measured in this paper, was compiled. Respondents rated on a five-point Likert scale.

\subsection{Participants and data collection}

The research was carried out in organizations in Serbia. According to the size, medium and large companies were included. According to the type of activity, production, service and public companies were included. Respondents were employed in these companies, regardless of gender and age. A total of 680 questionnaires were distributed, and 582 questionnaires were completed. 42 questionnaires were rejected due to incomplete responses. So, the final sample consists of 540 respondents from 72 companies (the percentage of successfully completed questionnaires was 79.4\%). 


\section{RESULTS}

\subsection{Descriptive statistics}

Table 1 shows the descriptive statistics for the all observed items and dimensions. Mean values and standard deviations for each items and dimension were calculated. The values of Cronbach's alpha were calculated for each dimension, and take the range from 0.807 to 0.954 .

Table 1: Descriptive statistics for the observed items and dimensions

\begin{tabular}{|l|c|c|c|c|c|c|c|}
\hline \multicolumn{1}{|c|}{ Items and dimensions } & Abbr. & $\mathbf{N}$ & Min & Max & Mean & $\begin{array}{c}\text { Std. } \\
\text { Dev. }\end{array}$ & $\boldsymbol{\alpha}$ \\
\hline Productivity & FP1 & 540 & 1.00 & 5.00 & 3.700 & .853 & \\
\hline Profitability & FP2 & 540 & 1.00 & 5.00 & 3.580 & .852 & \\
\hline Market share & FP3 & 540 & 1.00 & 5.00 & 3.540 & .866 & \\
\hline Sales growth & FP4 & 540 & 1.00 & 5.00 & 3.330 & .917 & \\
\hline Competitive status & FP5 & 540 & 1.00 & 5.00 & 3.580 & .926 & \\
\hline Asset growth & FP6 & 540 & 1.00 & 5.00 & 3.340 & .876 & \\
\hline Salaries & FP7 & 540 & 1.00 & 5.00 & 3.310 & .800 & \\
\hline Financial performance & FP & 540 & 1.28 & 5.00 & 3.484 & .677 & 0.891 \\
\hline Innovativeness & IN & 540 & 1.00 & 7.00 & 4.869 & 1.309 & 0.848 \\
\hline Proactiveness & PR & 540 & 1.00 & 7.00 & 5.770 & 1.136 & 0.820 \\
\hline Achievement & ACH & 540 & 1.00 & 7.00 & 5.217 & 1.191 & 0.866 \\
\hline Personal attitude & PA & 540 & 1.00 & 7.00 & 4.557 & 1.420 & 0.906 \\
\hline Subjective norm & SN & 540 & 1.00 & 7.00 & 5.074 & 1.309 & 0.807 \\
\hline Perceived behavioral control & PBC & 540 & 1.00 & 7.00 & 4.234 & 1.326 & 0.898 \\
\hline Entrepreneurial intention & El & 540 & 1.00 & 7.00 & 3.323 & 1.619 & 0.954 \\
\hline
\end{tabular}

\subsection{Correlation analysis}

Correlation analysis (Table 2) shows the impacts of the financial performance items and dimension on individual entrepreneurial orientation dimensions (risk-taking, innovativeness, proactiveness), achievement dimension and the theory of planned behaviour dimensions (personal attitude, subjective norm, perceived behavioural control, entrepreneurial intention). Pearson's correlation was used $(* \mathrm{p}<0.05 ; * * \mathrm{p}<0.01)$.

Table 2: Coefficients of correlation between the financial performance items and dimension and individual entrepreneurial orientation dimensions, achievement dimension and the theory of planned behavior dimensions

\begin{tabular}{|c|c|c|c|c|c|c|c|c|}
\hline & RT & IN & PR & ACH & PA & SN & PBC & EI \\
\hline FP1 & $.085^{*}$ & $.132^{* *}$ & $.175^{* *}$ & $.118^{* *}$ & .076 & $.099^{*}$ & $.106^{*}$ & .058 \\
\hline FP2 & .075 & $.115^{* *}$ & $.131^{* *}$ & $.125^{* *}$ & .076 & $.115^{\star *}$ & $.098^{*}$ & $.100^{*}$ \\
\hline FP3 & $.119^{* *}$ & $.169^{* *}$ & $.138^{* *}$ & $.140^{* *}$ & $.091^{*}$ & $.126^{* *}$ & $.110^{*}$ & $.126^{* *}$ \\
\hline FP4 & $.146^{* *}$ & $.185^{* *}$ & $.123^{* *}$ & $.143^{* *}$ & .063 & $.120^{* *}$ & $.093^{*}$ & $.116^{* *}$ \\
\hline FP5 & $.095^{*}$ & $.173^{* *}$ & $.113^{* *}$ & $.128^{* *}$ & .076 & $.116^{* *}$ & .061 & .065 \\
\hline FP6 & $.136^{* *}$ & $.185^{* *}$ & $.125^{* *}$ & $.113^{* *}$ & .061 & $.112^{* *}$ & $.138^{* *}$ & $.087^{*}$ \\
\hline FP7 & .008 & .047 & $.140^{* *}$ & $.110^{*}$ & -.011 & -.025 & .033 & -.029 \\
\hline FP & $.124^{* *}$ & $.187^{* *}$ & $.173^{* *}$ & $.161^{* *}$ & .080 & $.124^{* *}$ & $.118^{* *}$ & $.098^{*}$ \\
\hline
\end{tabular}

$* \mathrm{p}<0.05 ; * * \mathrm{p}<0.01$.

\subsection{Regression analysis}

Regression analysis (Table 3) shows the predictive effects of the financial performance items (independent variables) on individual entrepreneurial orientational dimensions (risk-taking, innovativeness, proactiveness), achievement dimension and the theory of planned behaviour dimensions (personal attitude, subjective norm, perceived behavioural control, entrepreneurial intention) (dependent variables). In Table 3, the statistically significant predictive effects are shown in bold font. 
Table 3: Regression analysis (independent variables: the financial performance items; dependent variables: individual entrepreneurial orientation dimensions, achievement dimension and the theory of planned behavior dimensions)

\begin{tabular}{|c|c|c|c|c|c|c|c|c|c|c|}
\hline \multirow{2}{*}{ Dep. } & \multicolumn{7}{|c|}{ Indep. } & \multirow{2}{*}{ F2 } & \multirow{2}{*}{ F } & \multirow{2}{*}{ Sig. } \\
\cline { 2 - 8 } & FP1 & FP2 & FP3 & FP4 & FP5 & FP6 & FP7 & \multirow{2}{*}{ R $^{2}$} & & \\
\hline RT & .030 & -.116 & .055 & .117 & -.011 & .107 & -.055 & $\mathbf{0 . 0 3 1}$ & 2.402 & .020 \\
\hline IN & .044 & -.127 & .061 & .084 & .069 &. $\mathbf{1 2 6}$ & -.036 & $\mathbf{0 . 0 5 1}$ & 4.052 & .000 \\
\hline PR & .162 & -.062 & .036 & .011 & .012 & -.002 & .092 & $\mathbf{0 . 0 4 0}$ & 3.205 & .002 \\
\hline ACH & .006 & .016 & .034 & .067 & .043 & -.014 & .073 & $\mathbf{0 . 0 2 9}$ & 2.261 & .028 \\
\hline PA & .034 & .002 & .077 & -.042 & .035 & .023 & -.052 & 0.012 & 0.912 & .497 \\
\hline SN & .001 & .024 & .056 & .010 & .047 & .067 & -.087 & $\mathbf{0 . 0 2 6}$ & 2.046 & .048 \\
\hline PBC & .054 & -.034 & .074 & -.024 & -.040 & .130 & -.032 & 0.023 & 1.779 & .089 \\
\hline EI & -.076 & .050 & .118 & .054 & -.036 & .041 & -.075 & 0.025 & 1.969 & .057 \\
\hline
\end{tabular}

\section{DISCUSSION}

\subsection{Discussion of the results of correlation analysis (verification of hypothesis H1)}

Table 2 shows that financial performance and financial performance dimensions, in most cases, have a statistically significant and positive impact on individual entrepreneurial orientation dimensions, achievement dimension and the theory of planned behavior dimensions. The FP - Financial performance dimension has the most significant impact. Such a result could be expected, given that this dimension is, practically, the summary of all financial indicators (financial performance items) used in the analysis. Of the individual items, FP3 - Market share, then FP4 - Sales growth and FP6 Asset growth have the strongest impact. The good position of the company in the market, as well as the growth of fixed assets are parameters that are easily visible to employees and which well represent the success and power of the company. The company then has a good atmosphere where the members support each other. All of this motivates employees to be committed to work. In such conditions, employees feel safe, confident, have a high opinion of their abilities and are confident in the support of colleagues. This results in statistically significant and positive correlations with the dimensions of PBC - Perceived behavioral control and SN - Subjective norm, and then with the dimension EI - Entrepreneurial intention. Very similar relationships apply to FP2 - Profitability (as well as FP - Financial performance).

The PA dimension - Perslonal attitude has a statistically significant correlation (positive) only with the FP3 - Market share. The explanation may be similar to the previous one: a good position of one's own company can direct an employee to notice and observe positive examples of entrepreneurial practice. Such approach then creates the perception that high market share and business success are actually commonplace, and sympathies for entrepreneurial business flourish.

Interestingly, the item FP7 - Salaries has the weakest impact. Thus, perceived salary levels do not have a significant impact on the individual entrepreneurial orientation dimensions, achievement dimension, and the theory of planned behavior dimensions. FP7 - Salaries is in the strongest correlation with PR - Proactiveness. Higher pay can motivate an employee to be proactive, but it may not encourage innovation, the need for achievement, nor diminish entrepreneurial attitudes and intentions. Likewise, low pay is not a sufficient motivator for the development of entrepreneurial intentions (there is a weak negative correlation between FP7 - Salaries and EI - Entrepreneurial intention, but not statistically significant). This result differs from the results of some existing research, whereby low pay (dissatisfaction with pay) promotes entrepreneurial intentions (Werner, Gast, \& Kraus, 2014; Sorgner \& Fritsch, 2018; Shinnar \& Young, 2008). It should be borne in mind that the aforementioned research was conducted in Germany and the USA, while the research presented in this paper was carried out in organizations in Serbia, where salaries can be said to be relatively low, employees are accustomed to such circumstances and no longer see them as an incentive for job change. In addition, low salaries appear to limit employees' safety and self-confidence, and thus entrepreneurial intentions remain low.

Based on the previous presentations, it can be concluded that there is a statistically significant influence of some financial performance items and the financial performance dimension on the individual entrepreneurial orientation dimensions, achievement dimension and the theory of planned behavior dimensions. In this way, the hypothesis H1 is confirmed.

\subsection{Discussion of the results of the regression analysis (verification of hypothesis H2)}


Table 3 shows the results of regression analysis of the predictive effects of financial performance items on individual entrepreneurial orientation dimensions, achievement dimension and the theory of planned behavior dimensions. Items FP6 - Asset growth and FP7 - Salaries show the most pronounced predictive effects. The result for item FP7 - Salaries is slightly different from the results of correlation analysis. Namely, in addition to the statistically significant and positive predictive effect on dimension PR - Proactiveness (according to correlation analysis), item FP7 - Salaries, now exhibits statistically significant and negative predictive effect on dimension SN - Subjective norms. Obviously, viewed in a broader context, due to the introduction of more independent variables in the analysis, low pay can produce support for people in the environment to leave such a job and start an entrepreneurial venture, precisely because of an understanding of the current, disadvantaged situation. On the contrary, in the case of high salaries, the employee's tendency to start his own business in such conditions may seem unjustified and the environment does not support for what is deemed as unnecessary.

According to Table 3, the corrected determination indexes $\mathrm{R}^{2}$ have low values, ranging from 0.012 to 0.051 . Nevertheless, most of these values are statistically significant. Viewed under individual dependent variables (individual entrepreneurial orientation dimensions, achievement dimension and theory of planned behavior dimensions), under the strongest predictive effects of financial performance items are the dimensions IN - Innovativeness and PR - Proactiveness. This result is consistent with the results of correlation analysis. On the other hand, under the worst predictive effect of financial performance items are the dimensions PA - Perslonal attitude, PBC - Perceived behavioral control and EI - Entrepreneurial intention, in which there are no statistically significant values of the corrected determination indexes $\mathrm{R}^{2}$.

Based on the mentioned above, it can be concluded that there are statistically significant predictive effects of some financial performance items on the individual entrepreneurial orientation dimensions, achievement dimension and the theory of planned behavior dimensions. In this way, the hypothesis $\mathrm{H} 2$ is confirmed.

\section{CONCLUSION}

Of the financial performance items, FP3 - Market share, FP4 - Sales growth and FP6 - Asset growth have the strongest influence on the individual entrepreneurial orientation dimensions, achievement dimension and theory of planned behavior dimensions. Among other things, these items have statistically significant and positive correlations with the dimensions of PBC - Perceived behavioral control and SN - Subjective norm, and then with the dimension EI Entrepreneurial intention. Dimension PA - Personal attitude has a statistically significant correlation (positive) only with the item FP3 - Market share. A good position and perspective of one's own company gives employees security and confidence, so from that perspective even entrepreneurial work seems like a perfectly good and feasible option, and entrepreneurial intentions develop.

The weakest influence is the item FP7 - Salaries. Perceived salary levels have no significant impact on the individual entrepreneurial orientation dimensions, achievement dimension, and the theory of planned behavior dimensions. However, regression analysis showed that item FP7 - Salaries, had statistically significant and negative predictive effect on dimension SN - Subjective norm. It can be concluded that the environment will more strongly support an employed person to leave a low-paying job (be more understanding about that person's position), while in the case of high salaries, that support may be withheld (not understanding why one leaves a well-paying job).

The previous conclusions answer the dilemma presented in the introduction: there can be no discussion of the existence of negative factors that, from the perspective of the financial position of the organization, motivate employees to entrepreneurship. Generally, entrepreneurial intentions, in employees of organizations in Serbia, do not arise because employees are dissatisfied with the possibly poor financial performance of their organization, but on the contrary, because good financial performance of the organization gives them security and faith in their own capabilities regarding the feasibility of an entrepreneurial venture.

The limitations of this research can be that it has been carried out in organizations in Serbia. Thus, the obtained results and conclusions can be applied to organizations in Serbia. However, it can be assumed that similar relationships exist in other countries, especially countries in the region and other countries in the transition process.

The theoretical significance of this research is that it addresses the topic of entrepreneurial intentions in employed persons, while very few scientific papers in the field of entrepreneurship have dealt with it. Of course, there are even fewer papers examining the impact of an organization's current financial performance on the entrepreneurial intentions of individuals employed by those organizations. The practical significance of the research is that it shows that employees should definitely be taken into account as potential entrepreneurs. Government strategies and institutions, responsible for fostering entrepreneurship, should include this population. This, above all, involves providing quality entrepreneurial training, but also adequate financial support for employees to start their own businesses.

\section{REFERENCES}

Ajzen, I. (1991). Theory of planned behavior. Organizational Behavior and Human Decision Processes, 50(2), 179-211. Ariyabuddhiphongs, V., \& Marican, S. (2015). Big Five Personality Traits and Turnover Intention Among Thai Hotel Employees. International Journal of Hospitality \& Tourism Administration, 16(4), 355-374. 
Ashforth, B.E., \& Saks, A.M. (1996). Socialization tactics: Longitudinal effects on newcomer adjustment. Academy of Management Journal, 39(1), 149-178.

Athayde, R. (2009). Measuring Enterprise Potential in Young People. Entrepreneurship Theory and Practice, 33(2), 481500.

Bolton, D.L., Lane, M.D. (2012). Individual Entrepreneurial Orientation: development of a measurement instrument. Education + Training, 54(2/3), 219-233.

Brandstätter, H. (2011). Personality aspects of entrepreneurship: A look at five meta-analyses. Personality and Individual Differences (Special Issue on Personality and Economics), 51(3), 222-230.

Feola, R., Vesci, M., Botti, A., \& Parente, R. (2019). The Determinants of Entrepreneurial Intention of Young Researchers: Combining the Theory of Planned Behavior with the Triple Helix Model. Journal of Small Business Management, 57(4), 1424-1443.

Hatak, I., Harms, R., \& Fink, M. (2015). Age, job identification, and entrepreneurial intention. Journal of Managerial Psychology, 30(1), 38-53.

Hisrich, R.D., Peters, M.P., \& Shepherd, D.A. (2008). Entrepreneurship, 7th ed., Zagreb: Mate. (in Croatian)

Hisrich, R.D., Langan-Fox, J., \& Grant, S. (2007). Entrepreneurship research and practice: A call to action for psychology. American Psychologist, 62, 575-589.

Hormiga, E., Hancock, C., \& Valls-Pasola, J. (2013). The relationship between employee propensity to innovate and their decision to create a company. Management Decision, 51(5), 938-953.

Hsu, D.K., Shinnar, R.S., Powell, B.C., \& Coffey, B.S. (2017). Intentions to reenter venture creation: The effect of entrepreneurial experience and organizational climate. International Small Business Journal: Researching Entrepreneurship, 35(8), 928-948.

Hughes, K. (2003). Pushed or pulled? Women's entry into self-employment and small business ownership. Gender, Work \& Organization, 10(4), 433-454.

Huyghe, A., \& Knockaert, M. (2015). The influence of organizational culture and climate on entrepreneurial intentions among research scientists. The Journal of Technology Transfer, 40(1), 138-160.

Hyytinen, A., \& IImakunnas, P. (2007). Entrepreneurial Aspirations: Another Form of Job Search? Small Business Economics, 29(1-2), 63-80.

Kautonen, T., Luoto, S., \& Tornikoski, E.T. (2010). Influence of work history on entrepreneurial intentions in 'prime age' and 'third age': A preliminary study. International Small Business Journal, 28(6), 583-601.

Khotin, L. (2016). Old and New Entrepreneurs in Today's Russia. Problems of Post-Communism, 43(1), 49-57.

Kickul, J. (2001). Promises Made, Promises Broken: An Exploration of Employee Attraction and Retention Practices in Small Business. Journal of Small Business Management, 39(4), 320-335.

Liñán, F., \& Chen, Y.W. (2009). Development and Cross-Cultural Application of a Specific Instrument to Measure Entrepreneurial Intention. Entrepreneurship Theory and Practice, 33(3), 593-617.

Mali, P., Kuzmanović, B., Nikolić, M., Mitić, S., \& Terek, E. (2019). Model of leadership and entrepreneurial intentions among employed persons. International Journal of Simulation Modeling, 18(3), 385-396.

Mallon, M., \& Cohen, L. (2001). Time for a change? Women's accounts of their move from organizational careers to selfemployment. British Journal of Management, 12(3), 217-230.

Marshall, D.R., \& Gigliotti, R. (2018). Bound for entrepreneurship? A career-theoretical perspective on entrepreneurial intentions. International Entrepreneurship and Management Journal. https://doi.org/10.1007/s11365-018-0523-6

Minarcine, S., \& Shaw, C. (2016). Motivations for entrepreneurship. International Journal of the Academic Business World, 10(2), 47-56.

Monsen, E., \& Boss, R.W. (2009). The Impact of Strategic Entrepreneurship Inside the Organization: Examining Job Stress and Employee Retention. Entrepreneurship Theory and Practice, 33(1), 71-104.

Mortan, R.A., Ripoll, P., Carvalho, C., \& Bernal, M.C. (2014). Effects of emotional intelligence on entrepreneurial intention and self-efficacy. Journal of Work and Organizational Psychology, 30(2014), 97-104.

Muzychenko, O. (2008). Cross-cultural entrepreneurial competence in identifying international business opportunities. European Management Journal, 26(6), 366-377.

Obschonka, M., \& Stuetzer, M. (2017). Integrating psychological approaches to entrepreneurship: the Entrepreneurial Personality System (EPS). Small Business Economics, 49(1), 203-231. 
Paul, J., \& Shrivatava, A. (2016). Do young managers in a developing country have stronger entrepreneurial intentions? Theory and debate. International Business Review, 25(6), 1197-1210.

Rafferty, A.E., \& Griffin, M.A. (2006). Perceptions of organizational change: A stress and coping perspective. Journal of Applied Psychology, 91(5), 1154-1162.

Shinnar, R.S., \& Young, C. (2008). Hispanic immigrant entrepreneurs in the Las Vegas metropolitan area: Motivations for entry into and outcomes of self-employment. Journal of Small Business Management, 46(2), 242-262.

Sorgner, A., \& Fritsch, M. (2018). Entrepreneurial career paths: occupational context and the propensity to become selfemployed. Small Business Economics, 51(1), 129-152.

Tan, J.J., \& Litschert, R.J. (1994). Environment-strategy relationship and its performance implications: An empirical study of the Chinese electronics industry. Strategic Management Journal, 15(1), 1-20.

Urban, B., \& Chantson, J. (2019). Academic entrepreneurship in South Africa: testing for entrepreneurial intentions. The Journal of Technology Transfer, 44(3), 948-980.

Virick, M., Basu, A., \& Rogers, A. (2015). Antecedents of Entrepreneurial Intention among Laid-Off Individuals: A Cognitive Appraisal Approach. Journal of Small Business Management, 53(2), 450-468.

Wang, D., Tsui, A.S., Zhang, Y., \& Ma, L. (2003). Employment relationships and firm performance: evidence from an emerging economy. Journal of Organizational Behavior, 24(5), 511-535.

Wang, H., Tsui, A.S., \& Xin, K.R. (2011). CEO leadership behaviors, organizational performance, and employees' attitudes. The Leadership Quarterly, 22(1), 92-105.

Werner, A., Gast, J., \& Kraus, S. (2014). The effect of working time preferences and fair wage perceptions on entrepreneurial intentions among employees. Small Business Economics, 43(1), 137-160. 